\title{
Diagnosis of Knowledge Management Process in Companies
}

\author{
Dorota Chmielewska-Muciek \\ Faculty of Economics \\ Marie Curie-Sktodoreska University in Lublin, Poland \\ dorota@poczta.umcs.lublin
}

\begin{abstract}
Purpose - The paper presents a description and research results pertaining to knowledge management process in companies representing Polish IT sector. The main objective of the study was to diagnose the process. The study embraces Probst, Raub, Romhardt's process knowledge management model. Therefore, the diagnosis pertained to locating, acquiring, developing, sharing, applying and maintaining knowledge. In order to supplement the description of the process, the following were included: association of the process with a strategy, companies' level of knowledge management implementation, causes and barriers for the application, tools and determinants facilitating the implementation, sources of knowledge.

Design/Methodology/Approach - In order to arrive at the objectives and obtain unbiased results, quantitative studies based upon surveys were conducted. The questionnaire contained questions pertaining to individual stages and additional aspects of knowledge management process. Respondents presented their views by means of a 4-point scale evaluating a particular area associated with the process and the intensity of its presence.

Findings - Research results enable the following observations to be made. Knowledge management in the studied organizations is a planned activity originating from the organization's strategy. The implementation of knowledge management is to improve the quality of services and boost client satisfaction. Structural solutions facilitating the implementation have been developed. All stages of knowledge management process have been implemented in the studied companies. However, the extent of the implementation varied. The creation of knowledge is the most popular. Its utilization - the least. Knowledge management processes in the studied companies face several obstacles limiting the effectiveness of the idea, such as insufficient interpersonal communication and inadequate management style.

Research limitations/implications - Research results obtained in the study do not offer opportunities for generalizations. On the other hand, results can be compared with those for other sectors or countries. In addition, the comparison of knowledge management processes in companies diversified with regards to size, form of ownership, type of activity would constitute an interesting research opportunity. In order to expand knowledge of the process, additional aspects of the individual stages of knowledge management and the process' determinants may also be considered. Originality/Value - In the theory of management, knowledge is frequently considered as a significant issue in economy. Therefore, the present study and paper constitute a contribution to the expansion of knowledge on the course, determinants, objectives, barriers and implementation of knowledge management.
\end{abstract}

Keywords - knowledge management, knowledge management process, company, IT sector, Poland.

\section{Psynergía}

International Journal of Synergy and Research Vol. 5, 2016 pp. $113-123$ 
IJSR 5

\section{The nature of knowledge management}

"Knowledge management is based upon the premise that just like people are unable to completely rely upon full capability of their minds, organizations are unable to fully utilize knowledge they possess. Owing to knowledge management, in the process of acquiring or creating knowledge, organizations seek potentially useful expertise. Such knowledge is rendered accessible to those who may use it in the time and place which maximize its effective application in order to exert a positive influence upon the organization's operations. In general, it is believed that if an organization is able to improve its effective application of knowledge by only a fraction, it will result in the emergence of significant advantages" (King, 2009, p. 3). The above-mentioned definition presents knowledge management as a process. It is defined by numerous authors from such a perspective. Perez and Ordóñez de Pablos define knowledge management as a process revolving around "creating or capturing knowledge, organizations, and offering value accumulated in knowledge, imparting it, and determining mechanisms of its utilization, including re-use, both by individuals and groups in an organization" (2003, p. 84). The process facilitates the realization of particular objectives of an organization by an application of various tools. According to Probst, Raub and Romhardt, knowledge management constitutes "an integrated set of actions whose objective lies in knowledge resources being properly molded" (2002, p.35). Such actions constitute a process encompassing location, acquisition, creation, dissemination, application and maintenance of knowledge. Therefore, the essence of knowledge management is found in an organization of processes which develop new knowledge and distribute it to those in need. Knowledge is rendered accessible in order to be applied in the future by the whole organization. All areas of knowledge are interconnected (Van der Spek and Spijkervet, 1997, p. 35).

As a consequence, process approaches to knowledge management are diverse. They differ in the number of stages and terminology. In addition, these individual stages are not equally significant in knowledge management. Some stages are indicated much more frequently than others. These include creation, acquisition, diffusion (both sharing and dissemination of knowledge) and application of knowledge. Knowledge creation is considered as the most critical stage. The fact was acknowledged in studies by Mertins, Heisig and Vorbeck (2003, pp. 5-7). On the basis of their studies, the authors indicated application, diffusion, creation and maintenance of knowledge as the most vital stages of knowledge management.

Knowledge management embodies a complex process. Its constituting elements are closely interconnected and one impacts others. Therefore, focusing on one or selected stages of knowledge management seems inappropriate. The process ought to be perceived and realized comprehensively.

Location of knowledge constitutes the first stage of the process. It revolves around sources of internal knowledge, including individual, group and one in the organization's surrounding environment, being revealed. According to Lapniewski and Szczerbicki, location of knowledge "pertains to revealing its sources and is also associated with developing methods for knowledge acquisition - via structuring intellectual resources of an organization and designing maps of knowledge location" (2006, p. 15). Identification of the sources "enables a necessary fragment of knowledge to be located" (Morawski, 
2006, p.75) and "constitutes a fundamental factor of it being applied at a later time" (Klincewicz, 2008, p. 90). There exist numerous sources enabling location of knowledge. Organizations utilize them to a various extent and take into account factors such as knowledge gap, costs of knowledge acquisition, prospective benefits of its possession, or its availability. Some organizations designate a special position designed for a search of information employees may require. Other companies use services of knowledge brokers.

Knowledge acquisition constitutes a stage which follows location. According to Latusek, it may have a dual understanding. First of all, it may be perceived as learning of organizations' members. Secondly, it may be viewed as a systematic monitoring of the surrounding environment and acquisition of knowledge regarding the market, competition, changing conditions of operation, which may subsequently serve for sound managerial decisions to be made (2008, p. 247). Holsapple and Joshi observed that knowledge acquisition "refers to an activity associated with the identification of knowledge in the surrounding environment, and its transformation into a representation which may be internalized and/or applied" (2004, p. 106).

The significance of knowledge acquisition from the surrounding environment results chiefly from the fact that it allows for the primary gap identified in the location stage to be minimized. Secondly, the acquired, current and well-adjusted to organizations' needs knowledge forms a basis for sound decisions to be made, and constitutes a success factor in modern business. Next, knowledge acquired from the environment may “considerably improve an organization's functioning and decrease costs of day-to-day operations because knowledge originating from other areas or cases may be applied to this effect" (Latusek, 2008, pp. 246-247). Companies seeking to acquire knowledge from the surrounding environment may do it by employing specialists, cooperating with other organizations, acquiring knowledge from market participants, purchasing products associated with knowledge (Probst, Raub and Romhardt, 2002, pp. 122-136).

Apart from the acquisition of knowledge, its development aims at bridging the gap in organizations' knowledge resources. Knowledge development is characterized by a growing theoretical and practical significance when compared with the acquisition stage. Stankiewicz explains such a tendency by stating that "acquired knowledge requires constant development. Otherwise, sooner or later it expires and ceases to be a resource helpful in creating a competitive advantage. At present, due to globalization of economies and growing competitiveness, expiration of knowledge is especially dynamic (...) Knowledge development presents a source of original knowledge i.e. one possessing characteristics of a strategic resource" (2006, p. 354). Creation of knowledge may occur in various places inside and outside of organizations. They may conduct own research, utilize internal sources of knowledge. They may also develop various types of research cooperation with external entities and utilize their sources of knowledge.

According to Wiig, sharing knowledge revolves around "distributing knowledge where it is required" (1997, p.76). It is a process of "mutual transfer of knowledge by people in communication and cooperation" (Mikuła, 2007, p.137). In addition, Mertins, Heisig and Vorbeck highlight cultural determinants of knowledge sharing and define these as "a part of corporate culture which facilitates active exchange of information, knowledge and experiences among employees and departments of the

\author{
Diagnosis \\ of Knowledge \\ Management \\ Process \\ in Companies
}


IJSR 5

company" (2003, pp. 5-7). Sharing knowledge is significant because if knowledge is not used and applied, and employees do not share it, it does not constitute an asset to the organization. Teamwork contributes to knowledge sharing the most. It may occur in the form of a community of practitioners, formal work groups, project teams, and informal networking. Sharing occurs during project work, discussions, group problem solving, day-to-day cooperation within teams representing a particular field, and alliances with entities in the surrounding environment. Apart from occurring among people, knowledge sharing may also be realized by means of direct contacts or via IT tools and systems.

Application of knowledge denotes it becoming tangible in the form of innovation, changes in the organization or in the product for end users. Application of knowledge in order to create something new and boost organizations' value constitutes a dominant interpretation. King, Chung and Haney claim that a natural consequence of knowledge sharing may be its "application in the process of development (development of various interpretations), infusion (identification of basic issues) and specification (compilation of several understandings by various people or groups) in order to be useful in facilitating innovation, joint learning, individual learning and/or joint problem solving. It may also be incorporated into procedures, systems, products and relations in organizations" (2008, p. 168). Van der Spek and Spijkervet define knowledge application as "use of knowledge in order to offer new products and services" (1997, p. 76).

Knowledge maintenance is an important stage of knowledge management. It is responsible for the emergence of organizational memory and prevents knowledge loss. Organizational memory consists of knowledge resources which are "available to all employees, and controlled by the whole organization instead of individual people" (Klincewicz, 2008, p. 80). It is a "source of knowledge for new cognitive activities" (Morawski, 2005, p. 46). It aims at "securing the organization's operation in the future" (Mikuła, 2007, p. 138). Knowledge maintenance is perceived as the most "technical" of all stages of the process due to the fact that it focuses on tools and procedures associated with storing knowledge. Such an approach is dictated by a rapid build-up of knowledge resources both in electronic and traditional form, the necessity of lowering costs of information processing and storage, and boost of efficiency of these activities. Naturally, what follows is an increase in the significance of tools and activities for knowledge storage, and focus on their optimization.

\section{Methodology}

The objective of the study was to identify knowledge management processes. Results were to enable knowledge management to be described. Details of the description were based upon several research problems posed in the form of the following research questions:

- Do companies realize knowledge management processes?

- Does the implementation of the process constitute an element of a strategy? What results are expected?

- Are conditions and solutions facilitating knowledge management developed?

- What aspects of the process are present? 
The study focused on knowledge management. Probst, Raub and Romhardt's knowledge management concept was applied in the study. In accordance with the model, the study pertained to the location, acquisition, creation, dissemination, application and maintenance of knowledge. Companies representing Polish IT sector constituted the object of the study.

The study utilized survey method with the use of a questionnaire. It consisted of questions regarding the evaluated stages of knowledge management and a few additional ones on its determinants. Respondents presented their views on the subject and identified individual stages of the process by means of a 4-point scale evaluating a particular area associated with the process and the intensity of its presence.

The study encompassed 100 companies representing Polish IT sector. There were 1 large, 10 medium, and 89 small companies among them. Various types of partnerships dominated (88). In addition, there were 5 state-owned enterprises, and 7 cooperatives. All of them handled manufacture of computer hardware, software, and provided IT-related services.

The sample featured 415 respondents consisting of IT managers and specialists.

\section{Knowledge management - research results}

The starting point of the knowledge management analysis in the evaluated companies was the establishment of the extent to which the process is applied in these organizations. The greatest number of respondents (33\%) declared their companies applied knowledge management. The second most numerous group (24.1\%) stated the need for knowledge management was present, however, the process was not applied. According to $19.5 \%$ of respondents, their companies plan to implement knowledge management or the implementation has already commenced. Lack of interest in knowledge management was expressed by $23.3 \%$ of respondents.

Possessing broad, comprehensive and in-depth knowledge in the state of changing environment, risk, and insecurity, constitutes a success factor. Knowledge management is critical, especially when strategic decisions are to be made. Knowledge management constituted an element of organizations' strategy $(72.9 \%)$. In order for the process to be implemented, employees occupying positions associated directly with the issue were appointed (69.3\%). The existence and application of measurement systems regarding knowledge management was acknowledged by $60.5 \%$ of respondents.

The following were enumerated as areas improved as a results of knowledge management's application:

- $\quad$ increase in the quality of services offered $-13.7 \%$;

- $\quad$ higher client satisfaction $-12.8 \%$;

- $\quad$ more efficient management $-12.5 \%$;

- $\quad$ higher work efficiency $-12.4 \%$;

- time savings $-11.9 \%$;

- $\quad$ higher competitiveness $-10.3 \%$.

The basis for knowledge management processes encompasses sources where data and information is stored. According to respondents, the Internet (8.1\%), internal

\author{
Diagnosis \\ of Knowledge \\ Management \\ Process \\ in Companies
}




\section{IJSR} 5

trainings $(7.9 \%)$, own experience $(7.6 \%)$, and databases present in companies $(7.3 \%)$ constitute knowledge sources applied the most.

The use of knowledge sources is enabled by tools facilitating fast penetration of information systems and swift information transfer. Research results indicate that two of these are used definitely the most frequently i.e. the Internet, indicated by $21.8 \%$ of respondents, and electronic mail selected by $18.6 \%$. In addition, the intranet $(10.3 \%)$, databases $(14.9 \%)$ and teleconferences $(10.3 \%)$ were indicated quite frequently as tools facilitating knowledge management.

Research results enable the following observation to be made. In the evaluated companies, stages of knowledge management are realized with varied intensity. Respondents scored knowledge creation the highest, whereas its application - the lowest. When arranging the stages of knowledge management according to percentage of respondents' indications, the following ranking emerges:

1. Knowledge creation $-66.6 \%$;

2. Knowledge location $-64.7 \%$;

3. Knowledge sharing $-60.6 \%$;

4. Knowledge maintenance $-60.4 \%$;

5. Knowledge acquisition $-53.7 \%$;

6. Knowledge application $-47.4 \%$.

Knowledge location scored high (64.7\%). According to respondents, only knowledge creation occurs more frequently. The diagnosis of knowledge location was based upon several issues. These pertained to the familiarity with knowledge sources i.e. people, databases, availability of information, security of information, and association of databases with key processes. In general, respondents expressed positive opinions upon the subject. Respondents evaluated the way the contents of the database match the organization's key processes as very high. In addition, employees' identification of individuals possessing specific knowledge as well as information stored in databases and document workflow systems was perceived as good. They also acknowledged the existence of the practice of isolating knowledge which is under protection. Shortcomings with regards to knowledge location are associated with the lack of particular pieces of information in databases.

The occurrence of knowledge acquisition in the evaluated companies was assessed relatively low (53.7\%) when compared with location, creation, sharing and maintenance

\section{Chart 1.}

Knowledge management process $(\%)$

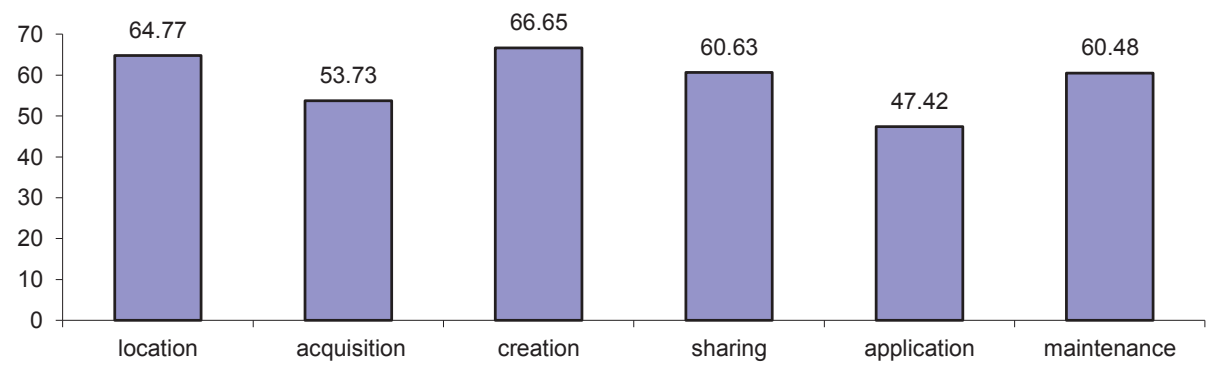

Source: Author's own study. 
of knowledge. Only knowledge application was evaluated lower. The assessment of this particular stage of the process pertained to several means of the acquisition such as employees' recruitment, services of consulting companies, cooperation with other organizations, outsourcing, purchase of products associated with knowledge. Respondents' evaluation of these activities associated with knowledge acquisition varies. Services of consulting companies were indicated as a very significant source of knowledge acquisition. Cooperation with other organizations was also seen as positive from the perspective of knowledge acquisition. On the other hand, according to respondents, other sources of knowledge acquisition, such as recruitment of employees possessing specific knowledge, outsourcing of particular processes, and purchase of products associated with knowledge, were insufficient.

Knowledge creation is the most frequently occurring stage of knowledge management (66.6\%).The following issues were included in its diagnosis: research and development infrastructure, purchase of $R \& D$ results, presence of conditions facilitating knowledge creation by employees, acceptance of mistakes being made, undertaking tasks enabling employees' individual knowledge to be developed. When analyzing research results in this area, multi-faceted activities enabling knowledge creation can be observed. Managers and specialists considered the purchase of $R \& D$ results as the chief source of knowledge creation. Apart from that, knowledge creation is facilitated by the presence of conditions encouraging employees to think independently, experiment, selfdevelop, and by the awareness that mistakes are allowed. Knowledge is also created by own research and development facilities.

Knowledge sharing and dissemination was assessed as high (60.6\%). The following were included in its assessment: the scope of information disseminated, the role of the department tasked with disseminating information, forms of information exchange, activities facilitating knowledge sharing and willingness to do it. Research results in this area present a positive picture of activities associated with knowledge sharing. Restricting the dissemination of information only to the type necessary for employees to conduct their duties, as well as initiating activities facilitating knowledge sharing among members of the organization, were evaluated the highest. In addition, the assessed companies systematize activities associated with knowledge transfer. The willingness to share information with other employees also constitutes a positive aspect.

Knowledge application was the least frequently selected stage of the process (47.4\%). The diagnosis of the stage was based upon the following: the purpose of new knowledge, preferred means of execution, convenience of application, activities facilitating knowledge application. Research results pertaining to this area indicate a diversified assessment of knowledge application. Positive aspects include: good organization of knowledge sources as far as their availability is concerned, inspiration for employees to apply knowledge at work which was derived from the surrounding environment, and acceptance for questions to be posed. At the same time, knowledge application is limited by a strong inclination of employees to apply the hitherto approaches, and associating new knowledge merely with its innovative application.

The final stage of knowledge management, its maintenance, was assessed rather high $(60.4 \%)$. It was evaluated on the basis of the following issues: information selection, updating databases, archiving knowledge of key employees, reviewing the usefulness

\author{
Diagnosis \\ of Knowledge \\ Management \\ Process \\ in Companies
}


IJSR 5 of knowledge, personal databases. When analyzing research results, it can be observed that numerous activates associated with archiving valuable knowledge are introduced. Knowledge to be archived is selected, databases are systematically updated, knowledge of key employees regarding the organization's processes is recorded, and apart from formal databases, employees develop their own systems for storing information. As far as knowledge maintenance is concerned, periodic review of employees' knowledge with regards to its utility seems rather poor.

\section{Conclusions}

Research results allow one to conclude that knowledge management is indeed practiced in the evaluated companies. The potential realization of the process may be also perceived by its actual, and prospective application, and awareness of the need for knowledge management. These symptoms prove an interest in knowledge management process exists.

In most cases, the introduction of knowledge management was associated with companies' strategies. As a consequence, knowledge management may serve as a tool for the realization of the strategy. It seems to disprove the idea being a short-lived trend in favor of it becoming applicable in practice. Skrzypek's results pertaining to the development of a strategy for knowledge management are different. They indicate that only $37 \%$ of the assessed organizations undertook the development of such a strategy, $34.8 \%$ did not make an effort to do so, and consequently, did not introduce the strategy into the general strategy of the organization $(2015$, p. 162). Furthermore, organizations' knowledge management is the most successful if external codification strategies are applied (Kim, Lee, Chun and Benbasat, 2014, p. 411).

When analyzing results pertaining to knowledge management, a few observations emerge. First of all, it seems that all stages of knowledge management process are implemented in the evaluated companies. However, their intensity varies. Knowledge creation was indicated to occur the most frequently. Then, knowledge location, sharing, maintenance, acquisition, and last but not least, application. Results obtained by the author differ from those by Stańczyk-Hugiet. Sharing knowledge and its dissemination were predicted to be the ones recognized the most. Knowledge application, creation, and location were also acknowledged (2007, pp. 13-14). On the other hand, results by Mertins, Heisig and Vorbeck indicated that respondents acknowledged knowledge application, diffusion, creation and maintenance as the most significant stages of knowledge management, the most frequently (2003, pp. 5-7).

Next, it seems that respondents are aware of the majority of various aspects associated with knowledge management. Most of the aspects were connected with knowledge creation and sharing. Few of them seem insignificant or poorly visible. These pertained mainly to knowledge application.

On the basis of research results, the most and the least significant aspects of knowledge management may be determined. The following may be considered as the former:

- contents of databases match the organization's key processes well $-79.76 \%$;

- $\quad$ selection of knowledge to be protected $-70.60 \%$; 
- cooperation with other organizations applied in order to acquire knowledge $-75.18 \%$;

- purchase of R\&D results from other organizations, including the specialized ones $77.59 \%$;

- development of conditions facilitating employees' independent thinking and experimenting $-70.18 \%$;

- $\quad$ systematic updates of databases $-69.64 \%$;

- $\quad$ archiving knowledge of key employees on organizations' processes $-70.85 \%$.

On the other hand, the greatest shortcomings of knowledge management are associated with:

- lack of databases or document flow systems providing employees with necessary information $-66.52 \%$;

- insufficient use of knowledge sources such as recruitment - 52.77\%, outsourcing $53.01 \%$, and products associated with knowledge $-53.25 \%$;

- $\quad$ application of new knowledge mainly for innovative solutions $-65.06 \%$;

- lack of periodic reviews regarding knowledge possessed by employees in order to assess its applicability $-58.76 \%$.

In general, the above results present a positive image of knowledge management. It results mainly from a systemic approach to knowledge management in the evaluated companies. It is manifested in:

- designating special positions tasked with knowledge management;

- developing measurement systems of knowledge management;

- utilization of diverse knowledge sources;

- utilization of a variety of tools facilitating knowledge management.

Skrzypek observed that $82.6 \%$ of respondents indicated instrumental aspects (decision-making, motivational tools and systems, the Internet, databases, methods) and $54.3 \%$ regarded institutional aspects pertaining to positions and teams associated with knowledge resources, as critical for successful knowledge management (2015, pp. 161-162).

Obviously, knowledge management faces organizational barriers limiting the idea's effectiveness in the assessed companies. The greatest of these can be seen in poor interpersonal communication $(21.7 \%)$ and inadequate management style $(20 \%)$. According to Flaszewska, technological and human barriers occur the least frequently. On the other hand, barriers associated with management methods emerge the most frequently as far as knowledge management is concerned (2016, pp. 57-58). Among the most contrasting factors process are organizational culture, organizational structure, IT information, common knowledge, psychical environment within the organizations (Becerra-Fernandez and Sabherwal, 2015, pp. 53-55).

Taking all the above into consideration, the fact that knowledge management is a planned activity resulting from an embraced strategy is acknowledged. The process realizes specific objectives. These include the increase in the quality of services, improved client satisfaction, growth in work efficiency, and improvement in the company's management process. Expectations regarding knowledge management are broad and diverse. As a consequence, the objectives of knowledge management indicated by Richter and others, which differ from those obtained by the author, are not surprising. Richter's objectives encompass efficient, goal-oriented employee

\author{
Diagnosis \\ of Knowledge \\ Management \\ Process \\ in Companies
}


IJSR 5

communication and avoidance of information overload, efficient knowledge transfer, the establishment of networks of experts, participation of employees and creation of open corporate culture, increased awareness and transparency, support for the innovation potential and secure the future viability of the enterprise(Richter, Stocker, Müller and Avram, 2013, pp. 141-142).

Actions associated with knowledge management in IT sector are perceived as a suitable example. On the basis of research results, an observation can be made that good practices do not pertain to each stage of knowledge management process. Some of them - knowledge creation, location, sharing and maintenance - are applied more frequently than the remaining ones. As a consequence, the studied companies are capable of developing new products or services on the basis of knowledge which is systematized and archived in databases, and based on synergies resulting from knowledge sharing. However, the ability is severely restricted by a relatively low application of knowledge both in possession of the company and the one acquired from the surrounding environment. The studied companies' knowledge management potential is far greater than its actual application. Undeniably, it hampers objectives of knowledge management, such as growth in the quality of services, higher client satisfaction, improvement of work efficiency, and improvement of management processes, being achieved. In addition, such state of affairs diminishes innovation, flexibility and adaptation of enterprises, which constitute fundamental attributes of severely competitive IT sector.

Research results of the present study enable the formulation of significant features of knowledge management and its realization. Therefore, they constitute background material which may serve for conducting comparative studies.

\section{References}

Becerra-Fernandez, I. and Sabherwal R. (2015). Knowledge Management: Systems and Processes, Routledge, New York.

Flaszewska S. (2016). Bariery utrudniające zarządzanie wiedzą w firmach hi-tech (Barriers Hindering Knowledge Management in Hi-Tech Companies), Research Papers of Wrocław University of Economics, 422.

Holsapple, C. W. and Joshi, K. D. (2004). Handbook on Knowledge Management. Knowledge Matters, Springer, Berlin-Heidelberg-New York.

Kim, T. H., Lee, J.-N., Chun, J. U. and Benbasat, I. (2014). Understanding the Effect of Knowledge Management Strategies on Knowledge Management Performance: A Contingency Perspective, Information \& Management, Vol. 51, No. 4, pp. 398-416.

King, W. R., Chung, T. R. and Haney, M. H. (2008). Knowledge Management and Organizational Learning, The International Journal of Management Science Omega, Vol. 36, No. 2.

King, W. R. (2009). Knowledge Management and Organizational Learning, [in:] W. R. King (Ed.), Knowledge Management and Organizational Learning, Springer, New York.

Klincewicz, K. (2008). Cele zarządzania wiedzą (The Objectives of Knowledge Management), [in:] D. Jemielniak and A. K. Koźmiński (Eds.), Zarzązanie od podstaw. Podręcznik akademicki (Management from Scratch. Academic Handbook), Wydawnictwa Akademickie i Profesjonalne, Warsaw.

Łapniewski, Z. and Szczerbicki, E. (2006). Modele zarządzania wiedzą (Models of knowledge management), [in:] K. Leja (Ed.), Zarzadzanie wiedza. Wybrane problemy (Management of Knowledge. Selected Issues), Wydawnictwo Politechniki Gdańskiej, Gdańsk. 
Latusek, D. (2008). Pozyskiwanie wiedzy z otoczenia. Wywiad gospodarczy. Relacje z partnerami oparte na wiedzy (Acquiring Knowledge of the Environment. Business Intelligence. Relationships with Partners Based on Knowledge), [in:] D. Jemielniak and A. K. Koźmiński (Eds.), Zarządzanie od podstaw. Podręcznik akademicki (Management from Scratch. Academic Handbook), Wydawnictwa Akademickie i Profesjonalne, Warszawa.

Mertins, K., Heisig, P. and Vorbeck, J. (2003). Knowledge Management. Concepts and Best Practices, Springer, Berlin-Heidelberg-New York.

Mikuła, B. (2007). Zarządzanie wiedzą w organizacjach (Knowledge Management in Organizations), [in:] B. Mikuła, A. Pietruszka-Ortyl and A. Potocki (Eds), Podstawy zarzadzania przedsiębiorstwami w gospodarce opartej na wiedzy (Fundamentals of Business Management in the Knowledge Economy), Difin, Warsaw.

Morawski, M. (2005). Ilościowe zarządzanie wiedzą - podejście zachodnie (Quantitative Knowledge Management - A Western Approach), [in:] K. Perechuda (Ed.), Zarzadzanie wiedza $w$ przedsiębiorstwie (Knowledge Management in the Enterprise), Wydawnictwo Naukowe PWN, Warsaw.

Morawski, M. (2006). Kluczowe przesłanki zarządzania wiedzą (Fundamental Objectives of Knowledge Management), [in:] G. Kobyłko and M. Morawski (Eds.), Przedsiębiorstwo zorientowane na wiedze (Knowledge-Oriented Enterprise), Difin, Warsaw.

Perez, J. R. and Ordóñez de Pablos, P. (2003). Knowledge Management and Organizational Competitiveness: A Framework for Human Capital Analysis, Journal of Knowledge Management, Vol. 7, No. 3, pp. 82-91.

Probst, G., Raub, S. and Romhardt, K. (2002). Zarzadzanie wiedza w organizacji (Knowledge Management in Organizations), Oficyna Ekonomiczna, Kraków.

Richter, A., Stocker, A., Müller, S. and Avram, G. (2013). Knowledge Management Goals Revisited. A Cross-Sectional Analysis of Social Software Adoption in Corporate Environments, The Journal of Information and Knowledge Management Systems, Vol. 43, No. 2, pp. 132-148.

Skrzypek, A. (2015). Zarządzanie wiedzą w ujęciu teoretyków oraz w opinii przedsiębiorstw laureatów Polskiej Nagrody Jakości (Knowledge Management as Perceived by Theoreticians and Businesses - Nominees of the Polish Quality Award), Scientific Journal of Matopolska School of Economics in Tarnów, Vol. 26, No. 1.

Stańczyk-Hugiet, E. (2007). Dyfuzja wiedzy (Diffusion of Knowledge), Ekonomika i Organizacja Przedsiębiorstwa, Vol. 10.

Stankiewicz, M. (2006). Próba modelowania procesów zarządzania konkurencyjnym potencjałem wiedzy w polskich przedsiębiorstwach (Attempt at Modeling the Competitive Potential of Knowledge Management in Polish Enterprises), [in:] M. J. Stankiewicz (Ed.), Zarzadzanie wiedza jako kluczowy czynnik międzynarodowej konkurencyjności przedsiębiorstwa (Knowledge Management as a Key Factor in the International Competitiveness of the Company), Wydawnictwo TNOiK - Dom Organizatora, Torun.

Van der Spek, R. and Spijkervet, A. (1997). Knowledge Management: Dealing Intelligently with Knowledge, [in:] J. Liebowitz and L. C. Wilcox (Eds.), Knowledge Management and Its Integrative Elements, CRC Press, Boca Raton, New York.

Wiig, K. M. (1997). Roles of Knowledge-Based Systems in Support of Knowledge Management, [in]: J. Liebowitz and L. C. Wilcox (Eds.), Knowledge Management and Its Integrative Elements, CRC Press, Boca Raton, New York.

Diagnosis
of Knowledge
Management
Process
in Companies

